Muller, S. A., Farrow, G. M., and Martalock, D. L. (1969). Archives of Dermatology, 100, 523.

O'Rourke, R. A., and Eckert, G. E. (1964). Archives of Internal Medicine, 113,191 .

Rees, R. B., Bennett, J. H., and Bostick, W. L. (1955). Archives of Dermatology, 72, 133.

Rolleston, Sir H., and McNee, J. W. (1929). Diseases of the Liver, Gallbladder, and Bile-Ducts. London, Macmillan.

Ryan, T. J., Vickers, H. R., Salem, S. N., Callender, S. T., and Badenoch, J. (1964). British fournal of Dermatology, 76, 555 .

Shapiro, H. A., Maibach, H., and Lee, J. (1970). Gastroenterology, 58, 1012.
Sharp, H., Nesbit, M., White, J., and Krivit, W. (1969). Fournal of Pediatrics, 74,818

Sherlock, S. (1968). Diseases of the Liver and Biliary System. Oxford, Blackwell Scientific.

Shuster, S., and Marks, J. (1970). Systemic Effects of Skin Disease. London, Heinemann Medical.

Stone, W. D., Islam, N. R. K., and Paton, A. (1968). Quarterly Fournal of Medicine, 37, 119.

Taft, L. I. (1965). Israel fournal of Medical Sciences, 1, 823.

Talerman, A., and Thompson, R. B. (1966). Fournal of Clinical Pathology, 19,81 .

\title{
Hypothalamic-pituitary-adrenal Function in Patients Treated with Long-term Depot Tetracosactrin
}

\author{
W. J. IRVINE， D. R. CULLEN， S. A. KHAN， J. G. RATCLIFFE
}

British Medical fournal, 1971, 1, 630-633

\section{Summary}

Four patients treated with depot tetracosactrin for 10 to 18 months maintained normal hypothalamic-pituitary-adrenal function assessed by the nyctohemeral variation of plasma corticosteroids and by the responses of plasma corticosteroids to insulin-induced hypoglycaemia, lysine-vasopressin, and depot tetracosactrin. The pituitary component of the response was analysed by measuring plasma immunoreactive ACTH levels. Three patients showed a nyctohemeral ACTH rhythm and normal ACTH responses to insulin-induced hypoglycaemia. Consistently undetectable morning plasma ACTH levels were found in the fourth patient, who also showed an unusually delayed rise in both ACTH and corticosteroid levels in response to insulin-induced hypoglycaemia, though the peak values attained were normal.

The lack of suppression of hypothalamic-pituitary-adrenal function together with the good clinical response in these four patients suggests that treatment with depot tetracosactrin should be considered when long-term corticosteroid therapy is required.

\section{Introduction}

It is well established that the administration of synthetic or natural corticosteroids over a prolonged period may be followed by suppression of hypothalamic-pituitary-adrenal function. Basal plasma ACTH levels, measured by bioassay (Graber et al., 1965) and radioimmunoassay (Besser et al., 1971), and corticosteroid levels are low initially after steroid withdrawal. An impaired corticosteroid response to insulininduced hypoglycaemia is also commonly found (Daly et al., 1967; Plumpton and Besser, 1969; Malone et al., 1970). In the latter studies, however, the distinction between a pituitary

\footnotetext{
Departments of Endocrinology and Therapeutics, Royal Infirmary, Edinburgh, and M.R.C. Clinical Endocrinology Unit, Edinburgh

W. J. IRVINE, B.SC., F.R.C.P.ED., Consultant Physician

Royal Infirmary, Edinburgh

D. R. CULLEN, M.B., M.R.C.P., Senior Registrar in Medicine

S. A. KHAN, M.R.C.P.ED., D.T.M.\&H., Senior Registrar in Dermatology

St. Bartholomew's Hospital, London E.C.1

J. G. RATCLIFFE, M.sc., B.M., Lecturer in Chemical Pathology
}

and an adrenal defect could not always be made in the absence of plasma ACTH measurements.

Reports on the effect of long-term porcine corticotrophin therapy on hypothalamic-pituitary-adrenal function (Bacon et al., 1968; Carter and James, 1970) have shown that most patients maintain normal or only marginally subnormal corticosteroid responses to insulin-induced hypoglycaemia and that prolonged daily corticotrophin therapy may offer a significant advantage over prolonged corticosteroid treatment.

The present paper reports hypothalamic-pituitary-adrenal function (assessed by nyctohemeral variation, insulin-induced hypoglycaemia, lysine-vasopressin, and tetracosactrin stimulation tests) in four patients treated with long-term depot tetracosactrin. Both plasma immunoreactive ACTH and fluorogenic corticosteroids were measured to analyse the hypothalamic-pituitary-adrenal response in terms of the pituitary as well as the adrenal components.

\section{Patients studied}

The clinical data and therapeutic history of the four patients studied are summarized in Table I. All four patients had an excellent clinical response to depot tetracosactrin (Synacthen Depot) (tetracosactrin adsorbed on to an inorganic zinc complex) treatment, and complications (pigmentation and fluid retention) occurred only with doses of $1 \mathrm{mg}$ twice weekly or greater. Local pain was experienced with subcutaneous but not with intramuscular injection. One patient (Case 3) was well controlled on prednisolone $30 \mathrm{mg} /$ day but developed hypertension, a Cushingoid appearance, and multiple vertebral fractures. Following the change to depot tetracosactrin there was some evidence of healing of the fractures. Case 4 was not controlled on betamethasone $2 \mathrm{mg} /$ day for two and a half years or corticotrophin gel 60 IU intramuscularly weekly for seven months.

\section{Methods}

Insulin-induced hypoglycaemia tests were performed four to six days after an injection of depot tetracosactrin by giving 0.15 unit of soluble insulin per $\mathrm{kg}$ body weight by rapid intravenous injection through an indwelling forearm cannula, a continuous slow intravenous infusion of saline having been set up one hour previously. Samples of blood were obtained via the cannula at $-30,0,+30,+60,+90$, and +120 minutes relative to the insulin injection, for determination of 
TABLE I-Summary of the Clinical and Investigative Findings in the Four Patients

\begin{tabular}{|c|c|c|c|c|c|c|c|c|c|c|c|c|}
\hline \multirow{4}{*}{$\begin{array}{l}\text { Case } \\
\text { No. }\end{array}$} & \multirow{4}{*}{\multicolumn{2}{|c|}{$\begin{array}{l}\text { Age } \\
\text { and } \\
\text { Sex }\end{array}$}} & \multirow{4}{*}{ Diagnosis } & \multirow{4}{*}{ Therapy } & \multirow{2}{*}{\multicolumn{2}{|c|}{$\begin{array}{c}\text { Resting } \\
\text { Plasma Levels } \\
(09.00 \mathrm{hr}) \\
\end{array}$}} & \multicolumn{6}{|c|}{ Plasma Levels in Response to: } \\
\hline & & & & & & & \multicolumn{3}{|c|}{ Insulin Hypoglycaemia } & \multicolumn{3}{|c|}{ Lysine-Vasopressin } \\
\hline & & & & & \multirow{2}{*}{$\begin{array}{c}\text { ACTH } \\
\text { (pg/ml) } \\
\text { Peak } \\
\text { Value }\end{array}$} & \multirow{2}{*}{$\begin{array}{c}\text { Fl.C.S. } \\
\text { (ug/100 ml) } \\
\text { (Mean and } \\
\text { Range })\end{array}$} & \multirow{2}{*}{$\begin{array}{c}\text { ACTH } \\
\text { (pg/ml) } \\
\text { Peak } \\
\text { Value }\end{array}$} & \multicolumn{2}{|c|}{$\underset{(\mu \mathrm{g} / 100 \mathrm{ml})}{\text { Fl.C.S. }}$} & \multirow{2}{*}{$\begin{array}{c}\text { ACTH } \\
\text { (pg/ml) } \\
\text { Peak } \\
\text { Value }\end{array}$} & \multicolumn{2}{|c|}{$\underset{(\mu \mathrm{g} / 100 \mathrm{ml})}{\text { Fl.C.S. }}$} \\
\hline & & & & & & & & $\begin{array}{l}\text { Peak } \\
\text { Value } \\
\end{array}$ & $\begin{array}{c}\text { Max. } \\
\text { Increment }\end{array}$ & & $\begin{array}{c}\text { Peak } \\
\text { Value }\end{array}$ & $\begin{array}{c}\text { Max. } \\
\text { Increment }\end{array}$ \\
\hline 1 & 61 & M. & $\begin{array}{l}\text { Siogren's syndrome, } \\
\text { rheumatoid arthritis, } \\
\text { lupus erythematosus }\end{array}$ & $\begin{array}{l}\text { Depot tetracosactrin } \\
0.5 \mathrm{mg} / \mathrm{S} \text {.C. twice weekly } \\
\text { for } 10 \mathrm{months}\end{array}$ & 80 & $14(18-11)$ & 190 & 23 & 13 & 120 & 24 & 12 \\
\hline 2 & 70 & M. & Exfoliative dermatitis & $\begin{array}{l}\text { Depot tetracosactrin } \\
1 \mathrm{mg} / \mathrm{S} \text {.C. twice weekly for } \\
1 \text { week, } 1 \mathrm{mg} / \mathrm{S} \text {.C. twice } \\
\text { weekly for } 2 \text { months. } 0.5 \mathrm{mg} \\
\text { I.M. twice weekly for } \\
18 \text { months }\end{array}$ & 50 & $17(22-12)$ & 230 & 32 & 16 & & Not done & \\
\hline 3 & & F. & $\begin{array}{l}\text { Rheumatoid arthritis, } \\
\text { lupus erythematosus }\end{array}$ & $\begin{array}{l}\text { Prednisolone } 30 \mathrm{mg} / \text { day orally } \\
\text { for } 4 \text { months in divided } \\
\text { doses. Depot tetracosactrin } \\
1 \mathrm{mg} / \mathrm{S} \text {.C. twice weekly for } \\
2 \text { weeks. } 0.5 \mathrm{mg} \text { I.M. twice } \\
\text { weekly for } 17 \text { months }\end{array}$ & 40 & $16(24-8)$ & 400 & 41 & 21 & & Not done & \\
\hline 4 & & F. & $\begin{array}{l}\text { Dermatitis } \\
\text { herpetiformis }\end{array}$ & $\begin{array}{l}\text { Dapsone } 100 \mathrm{mg} \text { day orally } \\
\text { Jan. } 1958-\text { Feb. } 1968 \text {. } \\
\text { Betamethasone } 2 \text { mg'day in } \\
\text { divided doses Dec. } 1964- \\
\text { June } 1967 \text {. Corticotrophin } \\
\text { gel } 60 \mathrm{I} . \mathrm{U} \text {. I.M. once weekly } \\
\text { Aug. } 1967 \text { - Feb. } 1968 \\
\text { followed by depot } \\
\text { tetracosactrin } 1 \mathrm{mg} \text { twice } \\
\text { weekly I.M. for } 2 \text { weeks. } \\
0.5 \mathrm{mg} \text {. twice weekly I.M. } \\
\text { for } 18 \text { months }\end{array}$ & 40 & $13(22-9)$ & $140^{D}$ & $\begin{array}{l}\text { yed respo } \\
\quad 38\end{array}$ & 14 & $\begin{array}{c}\text { Not } \\
\text { detectable } \\
(<<30)\end{array}$ & 33 & 19 \\
\hline
\end{tabular}

The treatment indicated was given sequentially up to the time of study. Fl.C.S. = Fluorogenic corticosteroids.

blood glucose, plasma ACTH, and fluorogenic corticosteroids. In all four patients the blood glucose fell to less than $20 \mathrm{mg} / 100 \mathrm{ml}$, and sweating occurred.

Lysine-vasopressin tests were performed in two patients (Cases 1 and 4) 48 hours after the insulin hypoglycaemia test, without further depot tetracosactrin. Plasma ACTH and corticosteroid levels were measured 30 minutes before, and every half hour for two hours after, the injection of 10 units of lysine-vasopressin intramuscularly. Dexamethasone was given orally to one patient (Case 1) in a dose of $0.5 \mathrm{mg}$ six-hourly, beginning 14 days after the last dose of depot tetracosactrin, and the plasma fluorogenic corticosteroid measurements were continued.

The interval between injections of depot tetracosactrin was increased from three to four days to at least eight days for the nyctohemeral rhythm studies. During this period plasma ACTH and fluorogenic corticosteroids were measured at $09.00,14.00$ and 23.00 hours daily. The corticosteroid responses to two injections of $0.5 \mathrm{mg}$ of depot tetracosactrin were also determined.

Plasma ACTH levels were measured by homologous radioimmunoassay (Landon and Greenwood, 1968) following extraction with porous glass (Ratcliffe and Edwards, 1971). All values are expressed in terms of a natural human ACTH preparation (Lerner Upton Fraction 8B). The antibody-combining site was directed towards the C-terminal part of the human ACTH molecule (amino-acids 25-39). Tetracosactrin (comprising the $\mathrm{N}$-terminal 24 amino-acids) showed less than $1 \%$ of the reactivity of the full molecule, which allowed measurement of the endogenous hormone in the presence of the synthetic peptide. The minimum level of ACTH detectable was $20 \mathrm{pg} / \mathrm{ml}$ when a $5-\mathrm{ml}$ plasma sample was extracted and an overnight assay incubation used, and correspondingly greater when smaller volumes were available. Antibodies to ACTH were determined by the method of Landon et al. (1967).

Plasma fluorogenic corticosteroids were measured by a modification of the method of Mattingly (1962). Blood glucose concentrations were assayed by an AutoAnalyzer method using glucose oxidase (Morley et al., 1968).

\section{Results}

The plasma corticosteroid levels at 09.00 hours and the nyctohemeral rhythm were within normal limits in all four patients within 72 hours of the last injection of depot tetracosactrin and for the following five to eight days of the study. The peak basal plasma ACTH values at 09.00 hours during these studies were greater than $40 \mathrm{pg} / \mathrm{ml}$ in all the patients (normal 09.00-10.00 hour levels in healthy adults range from undetectable $(<20)$ to $70 \mathrm{pg} / \mathrm{ml}$ ), though in Case 4 the levels exceeded $30 \mathrm{pg} / \mathrm{ml}$ on only one occasion in eight (Table I). The plasma ACTH was undetectable in all the 23.00 hour samples except one (normal adults show ACTH levels of $<20 \mathrm{pg} / \mathrm{ml}$ at this time). The nyctohemeral rhythm in plasma ACTH and corticosteroids in Case 2 is shown in Fig. 1. This also shows that the endogenous plasma ACTH levels are suppressed for 48 hours after $0.5 \mathrm{mg}$ of depot tetracosactrin. Dexamethasone given to Case 1 obliterated the corticosteroid nyctohemeral rhythm.

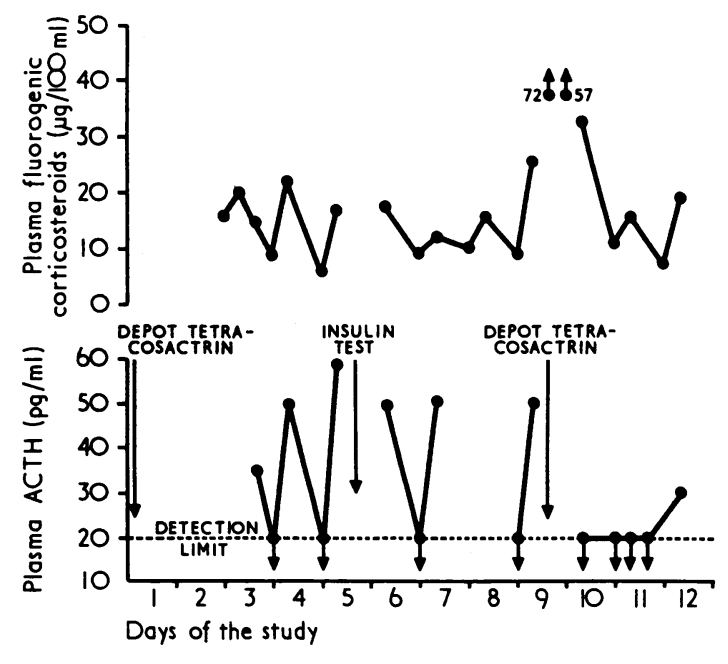

FIG. 1-Nyctohemeral rhythm studies in Case 2. 


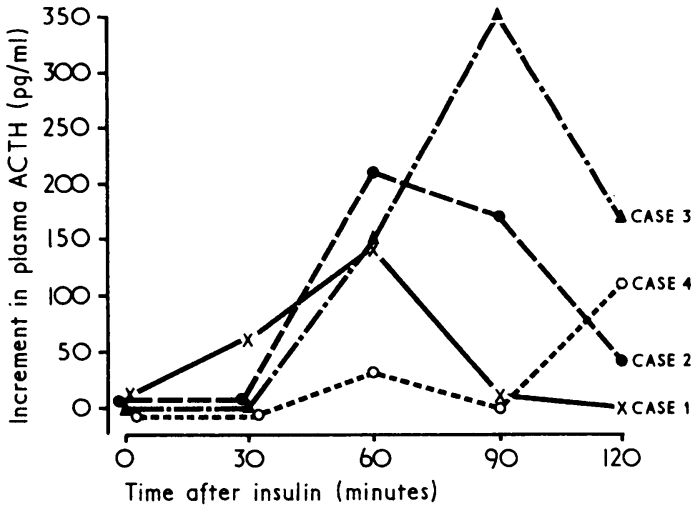

FIG. 2-Changes in plasma ACTH levels during insulin hypoglycaemia.
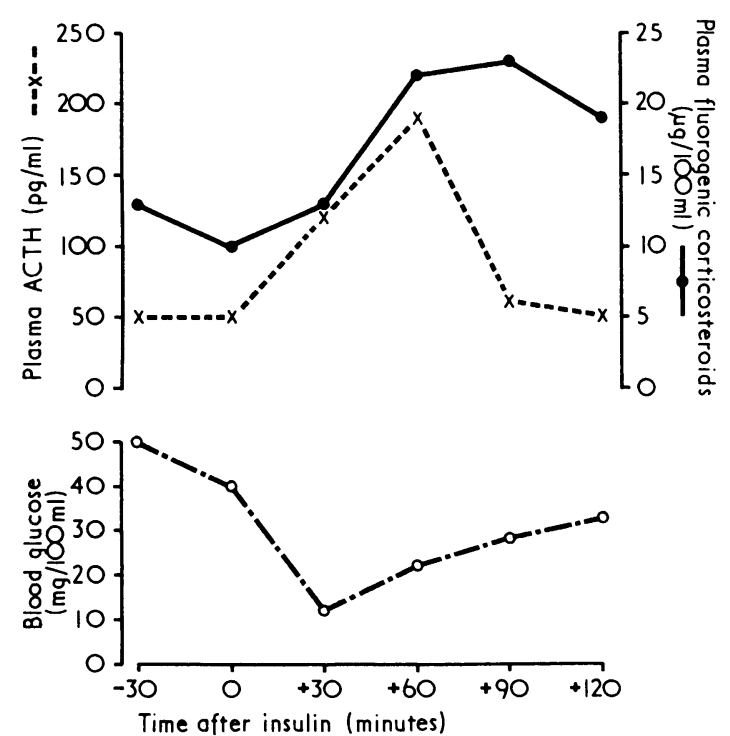

FIG. 3-Insulin-induced hypoglycaemia test in Case 1.

The increments in plasma ACTH in the four patients during insulin-induced hypoglycaemia are shown in Fig. 2. Three of the patients (Cases 1, 2, and 3) showed responses of plasma ACTH and corticosteroids similar to those found in normal subjects (Greenwood et al., 1966; Landon and Greenwood, 1968). In Case 4 the maximal rise in both plasma ACTH and corticosteroids was delayed (two hours after insulin) though the increase of corticosteroids achieved $(14 \mu \mathrm{g} / 100 \mathrm{ml})$ was normal. The relationship between the plasma ACTH, corticosteroids, and blood glucose during the insulin-induced hypoglycaemia test in Case 1 is shown in Fig. 3. The rise and fall of the plasma ACTH levels preceded that of the corticosteroids. The plasma ACTH levels showed an inverse relationship with the level of blood glucose.

The corticosteroid responses to the lysine-vasopressin test

TABLE II-Peak Plasma Fluorogenic Corticosteroid Levels 5-24 Hours after $0.5 \mathrm{mg}$ Depot Tetracosactrin. Measurements Following at Least Two Injections were made soon after Treatment Started (2-4 Weeks) and after a Prolonged Period of Treatment (10-18 Months)

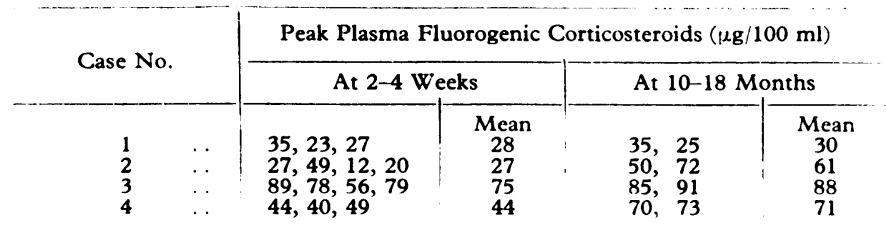

in the two patients studied (Cases 1 and 4) were normal, but a rise in ACTH was detected only in Case 1. This may be related to the timing of the samples, and lysine-vasopressin in the dosage used may be a less potent stimulus to ACTH release than insulin-induced hypoglycaemia.

The adrenocortical responses to $0.5 \mathrm{mg}$ of depot tetracosactrin intramuscularly at two intervals after starting treatment (2-4 weeks and 10-18 months) are shown in Table II.

\section{Discussion}

The effect of long-term depot tetracosactrin treatment on hypothalamic-pituitary-adrenal function has not been well established, because the synthetic preparation has been generally available for therapeutic purposes only since 1968. The assessment used in this study is based on tests considered to have the most clinical relevance (nyctohemeral variation following withdrawal of treatment, insulin-induced hypoglycaemia and intramuscular depot tetracosactrin tests). The measurement of both plasma ACTH and corticosteroid levels allows more detailed analysis of the separate contributions of pituitary and adrenal glands to the overall function.

Nyctohemeral rhythm in plasma corticosteroids was normal in all four patients within 72 hours of the last injection of depot tetracosactrin. This accords with the observation that the endogenous plasma ACTH levels were suppressed in Case 2 for 48 hours after depot tetracosactrin but were detectable at 72 hours. Plasma ACTH levels also showed a nyctohemeral variation in three patients; but in one (Case 4) the morning levels were not consistently detectable $(<30$ $\mathrm{pg} / \mathrm{ml}$ ). It is of interest that Case 4 also had unusually delayed plasma ACTH and corticosteroid response to insulininduced hypoglycaemia despite a normal glucose response, and no rise in ACTH was found following lysine-vasopressin though the corticosteroid response to lysine-vasopressin was normal. This is in keeping with the general finding that the corticosteroid response to insulin-induced hypoglycaemia is probably the most sensitive of the currently available tests for assessing hypothalamic-pituitary-adrenal function (Jacobs and Nabarro, 1969; Plumpton and Besser, 1969; British Medical fournal, 1970). The relation of this delayed response in Case 4 to the tetracosactrin therapy is complicated by the fact that this patient had had betamethasone $2 \mathrm{mg}$ /day for two and a half years before starting tetracosactrin, and it is known that occasional patients may not recover normal hypothalamic-pituitary-adrenal function for many years following steroid therapy (James, 1970). The possibility that this response was due to the development of antibodies to tetracosactrin was excluded by the insignificant antiserum titre found in this patient. The other three patients gave normal plasma ACTH and corticosteroid responses to insulin-induced hypoglycaemia. Thus the adrenal response to endogenous ACTH seems unimpaired in these patients.

The peak corticosteroid response to depot tetracosactrin was greater after prolonged treatment, but this alone does not constitute good evidence for adrenocortical hyperplasia in the absence of finding a decreased minimum effective dose of corticotrophin. However, since normal levels of 09.00 hour plasma corticosteroids were found in the days immediately following withdrawal of depot tetracosactrin treatment we suggest that the adrenal glands in these patients were not significantly hyperplastic. In patients treated with long-term daily porcine corticotrophin increased adrenal responsiveness has been reported (Bacon et al., 1968). Differences in adrenal response after corticotrophin therapy may be related to different dosage regimens, since Nelson et al. (1966) have shown that patients who have received corticotrophin gel once, twice, or thrice weekly do not show an enhanced response to tetracosactrin.

The satisfactory response of these patients to insulininduced hypoglycaemia contrasts with the high proportion of 
subnormal responses found in patients given intermittent cor ticosteroid therapy by Malone et al. (1970). This finding, together with the satisfactory clinical response in these patients with severe disease, suggests that a therapeutic trial of depot tetracosactrin in a dose of $0.5 \mathrm{mg}$ twice weekly should be considered for the control of disease requiring steroid therapy over a prolonged period. The effect of other dosage schedules on hypothalamic-pituitary-adrenal functon remains to be investigated. If these findings are confirmed in a larger series they may explain the clinical impression that it is easier to stop corticotrophin therapy than oral steroids and may therefore justify the use of depot tetracosactrin therapy in the treatment of exacerbations of chronic diseases.

We should like to thank Dr. I. W. Percy-Robb and the department of clinical chemistry, Edinburgh, Royal Infirmary, for the plasma fluorogenic corticosteroid and blood glucose determinations, Professor J. Landon and Dr. G. M. Besser for facilities and advice, and the McAlpine Trust and the Medical Research Council for financial support.

Requests for reprints should be sent to Dr. J. G. Ratcliffe, Department of Chemical Pathology, St. Bartholomew's Hospital, London E.C.1.

\section{References}

Bacon, P. A., Daly, J. R., Myles, A. B., and Savage, O. (1968). Annals of Rheumatic Diseases, 27, 7 .

Besser, G. M., Cullen, D. R., Irvine, W. J., Ratcliffe, J. G., and Landon, J. (1971). British Medical fournal, 1, 374.

British Medical fournal, 1970, 1, 644.

Carter, M. E., and James, V. H. T. (1970). Annals of Rheumatic Diseases, 29,73 .

Daly, J. R., Myles, A. B., Bacon, P. A., Beardwell, C. G., and Savage, 0 (1967). Annals of Rheumatic Diseases, 26, 18

Graber, A. L., Ney, R. L., Nicholson, W. E., Island, D. P., and Liddle, G. W. (1965). Fournal of Clinical Endocrinology and Metabolism, 25, 11.

Greenwood, F. C., Landon, J., and Stamp, T. C. B. (1966). Journal of Clinical Investigation, 45, 429.

Jacobs, H. S., and Nabarro, J. D. N. (1969). Quarterly fournal of Medicine, 38, 475.

James, V. H. T. (1970). Pharmacologia Clinica, 2, 182

Landon, J., Friedman, M., and Greenwood, F. C. (1967). Lancet, 1, 652

Landon, J., and Greenwood, F. C. (1968). Lancet, 1, 273.

Malone, D. N. S., Grant, I. W. B., and Percy-Robb, I. W. (1970). Lancet, 2,733 .

Mattingly, D. (1962). Fournal of Clinical Pathology, 15, 374.

Morley, G., Dawson, A., and Marks, V. (1968). Proceedings of the Association of Clinical Biochemists, 5, 42 .

Nelson, J. K., Mackay, J. S., Sheridan, B., and Weaver, J. A. (1966). Lancet, 2,78.

Plumpton, F. S., and Besser, G. M. (1969). British fournal of Surgery, 56, 216.

Ratcliffe, J. G., and Edwards, C. R. W. (1971). Radioimmunoassay Methods: European Workshop, ed. K. E. Kirkham and W. M. Hunter. Edinburgh, Livingstone. In press.

\title{
Trial of New Bronchodilator, Terbutaline, in Asthma
}

\author{
BERNARD J. FREEDMAN
}

British Medical fournal, 1971, 1, 633-636

\section{Summary}

Terbutaline, a new bronchodilator acting on $\beta$-adrenergic receptors, was given to 10 asthmatic patients, who received on separate days $5 \mathrm{mg}$ orally, $10 \mathrm{mg}$ orally, and $0.25 \mathrm{mg}$ subcuraneously. The ventilatory response was assessed by measurement of the FEV $_{1}$ before and at intervals after administration. The cardiovascular response was assessed by measurement of the heart rate and blood pressure and by electrocardiography at the same times as spirometry was performed.

The ventilatory response to all three doses and by both routes was satisfactory. The maximal increase in FEV $_{1}$ after 5 mg orally was only slightly less than that after $10 \mathrm{mg}$. The maximal increase in heart rate after $5 \mathrm{mg}$ orally was about half that which occurred after $10 \mathrm{mg}$. It is concluded that 5 $\mathrm{mg}$ orally and $0.25 \mathrm{mg}$ subcutaneously are suitable doses.

In general a modest fall in blood pressure affected the diastolic more than the systolic. On E.C.G. the $T$ wave was often depressed, and in one patient, it was inverted. A trough-like depression of the QRS baseline occurred several times. The significance of the E.C.G. changes is uncertain.

\section{Introduction}

In the search for a bronchodilator drug with optimal adrenergic activity on $\beta$-receptors, Bergman et al. (1969) studied sev-

King's College Hospital, London S.E.5

BERNARD J. FREEDMAN, F.R.c.P., Consultant Physician

eral compounds for their balance of $\beta_{1}$ and $\beta_{2}$ activity (Lands et al., 1966, 1967). Terbutaline, synthesized by Wetterlin and Svensson in 1966, was selected for further study. Its structural formula (Fig. 1) differs from that of orciprenaline in having a tertiary butyl group at the nitrogen atom instead of an isopropyl group. Relatively large $\beta_{2}$ and small $\beta_{1}$ effects were observed and subsequently confirmed by Persson and Olsson (1970). Arner et al. (1970a) found that equal subcutaneous doses of terbutaline and orciprenaline caused similar maximal increases in heart rate which appeared to persist slightly longer after terbutaline. Orally terbutaline $5 \mathrm{mg}$ and orciprenaline $20 \mathrm{mg}$ caused equal increases in heart rate but orciprenaline caused a greater stroke volume. Carlström and Westling (1970) confirmed a preferential action on $\beta_{2}$ receptors. A bronchodilator response in asthmatics was observed after terbutaline was given subcutaneously (Arner et al., 1970b) and orally (Mattila and Muittari, 1969; Arner, 1970; Formgren, 1971).

The following is an account of the ventilatory and cardiovascular response to terbutaline in 10 asthmatic patients.

\section{Materials and Methods}

The patients were selected for their known responsiveness to bronchodilator drugs and for the small spontaneous variation in the degree of their bronchospasm over comparatively long periods. At the time of testing they were in remission from acute exacerbation. Their clinical characteristics are shown in Table I.

Terbutaline was administered on separate days, $5 \mathrm{mg}$ orally, $10 \mathrm{mg}$ orally, and $0.25 \mathrm{mg}$ subcutaneously. It was given on three consecutive days or at weekly intervals acconding to the patient's convenience. The order of these three presentations was randomized. To ensure rapid absorption the oral tablets were fragmented and taken with $7 \mathrm{oz}(200 \mathrm{ml})$ of water three hours after a light breakfast. 